\title{
Recovery of Tail-Elicited Siphon-Withdrawal Reflex Following Unilateral Axonal Injury Is Associated with Ipsi- and Contralateral Changes in Gene Expression in Aplysia californica
}

\author{
Florence Noel, William N. Frost, Lian-Ming Tian, Michael A. Colicos, and Pramod K. Dash \\ Department of Neurobiology and Anatomy, University of Texas-Houston Health Science Center, Houston, \\ Texas 77225
}

\begin{abstract}
Behavioral, cellular and molecular changes were examined following axonal injury in the marine mollusc Aplysia californica. Unilateral nerve injury was performed by crushing the pleural-pedal connective and the peripheral pedal nerves innervating one side of the posterior body wall and the tail. The injury procedure severs the axons of the pleural sensory neurons resulting in the blockade of the tailelicited siphon-withdrawal reflex. Partial reflex recovery is observed within $3 \mathrm{~d}$ and reaches $50 \%$ of the pretest value by six weeks postinjury. Retrograde staining of injured nerves combined with electrophysiological recordings from siphon motor neurons show that axons can regenerate through the crushed site and reconnect with the tail by three weeks postinjury. Moreover, the behavioral and electrophysiological measurements suggest that the contralateral sensory neurons may contribute to the early recovery of the siphon-withdrawal reflex. The levels of mRNAs coding for actin and calreticulin are elevated while the mRNAs coding for intermediate filament protein, sensorin A, FMRFamide are reduced in the ipsilateral pleural ganglia as detected by Northern blots. In the contralateral pleural ganglia, the levels of mRNAs coding for actin, sensorin A and FMRFamide are elevated. These molecular changes in both the ipsi- and contralateral sides are consistent with the hypothesis that both sldes are particlpating In the behavioral recovery following unilateral axonal injury.

[Key words: tail-elicited siphon withdrawal, axonal regeneration, mechanosensory neuron, messenger RNA, actin, intermediate filament protein, calreticulin, sensorin $A$, FMRFamide]
\end{abstract}

Axonal regeneration following nerve injury appears to involve changes in gene expression and protein synthesis (Skene, 1989). The molecular cascades triggered by injury that cause these changes necessary for the regeneration and reestablishment of functional synapses, however, are poorly understood. In the present study, we have examined the levels of mRNA encoding po-

\footnotetext{
Received Feb. 1, 1995; revised June 16, 1995; accepted June 20, 1995

We thank J. R. Goldsmith and M. F. Dulin for their help with the behavioral studies and injury protocol, and A. N. Moore, L. J. Cleary, J. H. Byrne, and A. Eskin for their comments on the manuscript. This work was supported by a fellowship from Klingenstein Foundation and NIH Grants MH49962 to P.K.D. and MH4853640 to W.N.F.

Correspondence should be addressed to P. K. Dash, Department of Neurobiology and Anatomy, University of Texas-Houston Health Science Center, P.O. Box 20708, Houston, TX 77225.

Copyright $\mathcal{C} 1995$ Society for Neuroscience $0270-6474 / 95 / 156926-13 \$ 05.00 / 0$
}

tential injury-related proteins in the marine mollusc Aplysia californica following unilateral nerve crush. Due to its accessible and symmetric nervous system, Aplysia has been used as a model system to investigate behavioral, cellular and molecular changes following axonal injury (Aletta and Goldberg, 1982; Fredman 1988; Scott and Kirk, 1992). For example, injury to ventrocaudal (VC) mechanosensory neuron axons blocks the tail-elicited siphon-withdrawal reflex and leads to increased sensory neuron excitability (Walters et al., 1991). Axotomy of the giant metacerebral cell (MCC) causes changes in the rate of synthcsis of specific protcins including a $60 \mathrm{kDa}$ neurofilamentlike protein (Savage et al., 1990). Injury to the axon of R2 alters the synthesis of several nuclear proteins including a $41 \mathrm{kDa}$ CREB (cAMP response element binding)-like protein (Buriani et al., 1990). Recently, a $97 \mathrm{kDa}$ phosphoprotein (sp97) containing a nuclear targeting sequence has been identified in injured pedal nerves which has been hypothesized to transmit the signal from the site of injury to the nucleus (Ambron et al., 1993; Elliot et al., 1993; Schmied et al., 1993). However, the role of sp97 in altering gene expression is not yet known.

Injury-induced changes in expression of genes encoding structural proteins and neuropepetides have been observed in mammals. Altered expression of structural proteins such as actin, tubulin, neurofilaments and a growth associated protein (GAP43) in the injured neurons have been correlated with axonal regeneration (Skene and Willard, 1981; Hall, 1982; Hoffman et al., 1987; Tetzlaff et al., 1988; Oblinger et al., 1989). Alterations in expression of neuropeptide genes (Rutherford et al., 1992; Zhang et al., 1993) and tyrosine hydroxylase (Koo et al., 1988) have also been observed following axonal injury. Interestingly, it has been reported that injury-related changes in uninjured contralateral neurons contribute to behavioral recovery. For example, in cat hemisected spinal cord, recovery of reflexes and locomotion involves sprouting in contralateral pathways (Helgren and Goldberger, 1993). Sprouting of undamaged pathways following injury has also been reported in frog motor ncurons and rat dentate gyrus following unilateral injury (Steward et al., 1976; Rotshenker, 1982). The injury-induced signal(s) that alters gene expression and causes sprouting are not known at present.

In order to begin an investigation of molecular cascades underlying nerve injury-induced axonal regeneration, we examined the recovery of the tail-elicited siphon-withdrawal reflex in Aplysia at different times following unilateral nerve crush. The response of the left F-cluster siphon (LFS) motor neurons to nerve and tail stimulation as well as changes in gene expression were investigated. Axonal regeneration and recovery of the reflex 


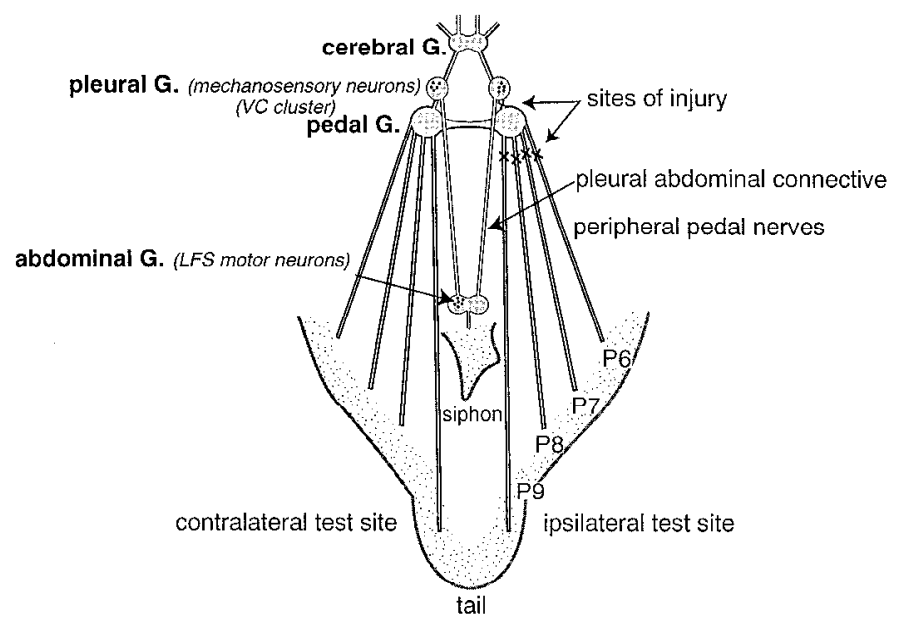

Figure 1. Schematic diagram of the Aplysia central nervous system indicating the sites of nerve crush. Pedal nerves $(P 6, P 7, P 8, P 9)$ innervating one-half of the tail and body wall and the pleural-pedal connective were crushed using fine forceps. Siphon contraction is mediated by LFS motor neurons located in the abdominal ganglion. A stimulus applied to the body wall or tail activates the pleural mechanosensory neurons. These neurons, in turn, activate the LFS motor neurons via the pleural-abdominal connective and elicit siphon withdrawal. Crushing of the peripheral nerves and the pleural-pedal connective blocks the siphon-withdrawal caused by ipsilateral body wall or tail stimulation. Ganglion $(G)$ names are presented in bold.

were associated with changes in mRNA expression of two structural proteins, actin and intermediate filament protein (IF protein), of a calcium binding protein, calreticulin and of two neuropeptides, sensorin A and FMRFamide. Changes were detected in both the ipsilateral and contralateral pleural ganglia. These findings, together with the electrophysiological measurements, suggest that both damaged and undamaged neurons are contributing to the recovery of the reflex.

\section{Materials and Methods}

Injury paradigm. Aplysia californica $(100-250 \mathrm{gm})$ were obtained from Alacrity Marine Biological (Redondo Beach, CA). Animals were main tained in artificial sea water (Instant Ocean, Aquarium systems, Mentor, $\mathrm{OH})$ at $15^{\circ} \mathrm{C}$. The animals were allowed to recover from shipment for at least $5 \mathrm{~d}$ before any experimental manipulation. In designing the study, our goal was to maximize the likelihood of detecting injury related genomic changes following unilateral axonal injury in both the pleural and the pedal ganglia. To accomplish this, we injured peripheral pedal nerves as well as the pleural-pedal connective. Surgery and injury were performed as described by Walters et al. (1991) with the following modifications. The animals were anesthetized by injecting one third their body weight of cold isotonic ( $363 \mathrm{~mm}$ ) $\mathrm{MgCl}_{2}$ into the neck region and kept in artificial sea water maintained at $0^{\circ} \mathrm{C}$ for $10 \mathrm{~min}$. A $2 \mathrm{~cm}$ incision was made in the dorsal head region to expose the ring ganglia (cerebral ganglion, right and left pleural, and pedal ganglia). The nerves innervating a randomly chosen side of the body wall were crushed while the contralateral nerves were untouched. Nerve crushing was performed under a dissection microscope using fine forceps. The crush transected the axons but not the surrounding sheath. The pleural-pedal connective on the injury side was also crushed (Fig. 1). The pleural-pedal crush would sever axons of sensory neurons and interneurons while the peripheral nerve crushes would sever sensory and motor neurons. The incision was closed using silk sutures and the animals were allowed to recover in artificial sea water at $15^{\circ} \mathrm{C}$. The sham operated animals underwent an identical surgical procedure but received no nerve crush.

Behavioral measurements. The neuronal circuits controlling the tailelicited siphon-withdrawal reflex have been extensively studied (Carew et al, 1981; Walters et al., 1983; Byrne, 1987; Wright et al., 1991; Cleary and Byrne, 1993; Raymond and Byrne, 1994; Xu et al., 1994). This reflex was measured in each animal several hours before surgery, and then at specific time points up to 6 weeks after surgery. Our measurement method was similar to that used in other studies (Castellucci et al,, 1988; Goldsmith and Byrne, 1993). Siphon-withdrawals were elicited by applying a mild electrical shock ( $2 \mathrm{~mA}, 40 \mathrm{msec}, 60 \mathrm{~Hz} \mathrm{AC}$ current) to the surface of the tail and posterior body wall, using a twowire submersible electrode. This test stimulus always elicited siphonwithdrawal in noninjured animals and produced no inking or injury to the skin. The siphon contracted immediately upon the application of the test stimulus. Over time, the length of the siphon decreased and then began to increase back to its original length. The duration of the siphon withdrawal was measured with a stopwatch from stimulus onset to the time the siphon stopped moving. For each test, a single siphon withdrawal score was obtained from the average of five consecutive measurements (interstimulus interval of one minute). Behavioral studies by others have sometimes surgically removed the parapodia to more easily measure the duration of the siphon withdrawal (Pinsker et al., 1973; Wright et al., 1991; Goldsmith and Byrne, 1993). This was not done in our study in order to avoid additional injury to the animal, which might have complicated the interpretation of the data. Due to the highly visible contraction of the body wall in injured animals, post-injury testing could not be performed blind. However, the experimenter was kept blind regarding the results from previous tests.

Axonal backflling. To detect axonal regeneration, retrograde filling of peripheral nerves was performed using nickel-lysine as described by Fredman (1987, 1988). Peripheral pedal nerves P6, P7, P8, and P9 were cut at $4 \mathrm{~cm}$ distal to the pedal ganglia. The ring ganglia (left and right pleural-pedal ganglia and cerebral ganglion) and peripheral pedal nerves were removed from the animal and pinned on the floor of a three milliliter chamber containing buffered filtered sea water (BFSW: artificial seawater containing $30 \mathrm{~mm}$ HEPES $\mathrm{pH} 7.6,100 \mu \mathrm{g} / \mathrm{ml}$ streptomycin, $1000 \mathrm{U} / \mathrm{ml}$ penicillin-G). The cut ends of ipsi- and contralateral peripheral pedal nerves were placed through a slot in a compartment adjacent to the chamber. The slot was then sealed with silicone vacuum grease to isolate the compartments. A drop of distilled water was placed over the cut end of the nerves to swell the axon. An equal volume of nickellysine solution ( $1 \mathrm{M} \mathrm{NiCl}_{2}, 4 \mathrm{M}$ lysine free base, $\mathrm{pH} 7.4$ ) was then added. Axons were allowed to fill for $24 \mathrm{hr}$ at room temperature. The ganglia and the cut end of the nerves were then thoroughly washed with BFSW. A solution of dithioximide $(10 \mathrm{mg} / \mathrm{ml}$ in dimethyl sulfoxide) was used to precipitate the nickel. The nervous system was then fixed in $10 \%$ formalin, bleached in methyl salicylate and mounted for visualization.

Electrophysiological recordings. A semi-intact preparation was used to test for functional regeneration of the transected sensory neuron axons. Animals were anaesthetized as described earlier. A reduced experimental preparation was then prepared, consisting of the tail, the cerebral, pleural, pedal, and abdominal ganglia, and their connecting nerves (Fig. 1). All peripheral nerves were cut except for pedal nerves P6, P7, P8, and P9 on both sides, leaving intact these polysynaptic pathways from the tail to the abdominal ganglion. In each preparation, one or two abdominal ganglion LFS siphon motor neuron candidates (Carew et al., 1981) were impaled with $3 \mathrm{M} \mathrm{KCl}$ intracellular electrodes. The LFS candidates were identified on the basis of their size, spontaneous activity, and location; however, their ability to produce siphon movements was not tested. For simplicity, throughout the article we refer to these neurons as LFS cells. Once penetrated, responses of the LFS cells to tail pinches (administered with hand-held forceps) were recorded. We chose to record responses of motor neurons rather than sensory neurons because the motor neurons receive polysynaptic input from most or all sensory neurons, and therefore are a point from which functional regeneration of the tail sensory neuron population as a whole can be monitored. In many experiments, after obtaining initial LFS responses to tail pinch the remaining pedal nerves were cut in particular sequences to identify the nerves conveying the stimulus. In some cases, particularly those in which no LFS response had been obtained to tail pinch, these nerves were then acutely crushed at different points distal to the injury site in order to determine the extent of sensory neuron regeneration. LFS responses to these stimuli indicated the presence of regenerated, electrically active axons through the sites of injury all the way to the site of acute crush.

Probe preparation. The cDNA clones encoding Aplysia actin (pLT25) and Aplysia sensorin A (SCR2; Brunet et al., 1991) were kindly made available by Dr. E. R. Kandel, Columbia University. The cDNA clone encoding Aplysia FMRFamide (FMRF-1; Schaefer et al., 1985) was kindly made available by Dr. R. Scheller, Stanford University. The plasmid containing the cDNA inserts were digested with EcoR1 and 


\section{A1. Non-Injured Nerve}

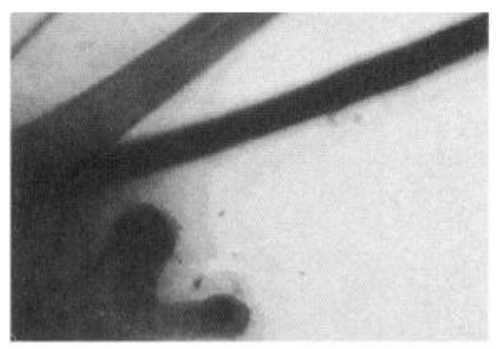

Proximal

B1. Stimulation of Healthy P9

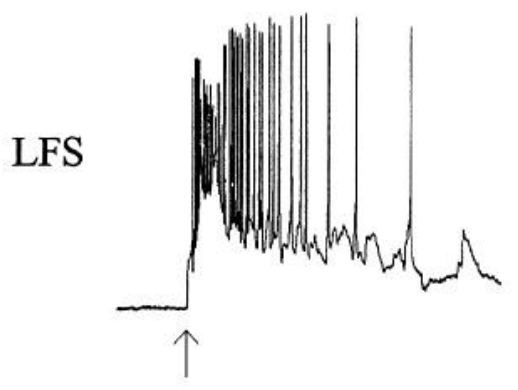

\section{A2. Nerve One Hour After Injury}

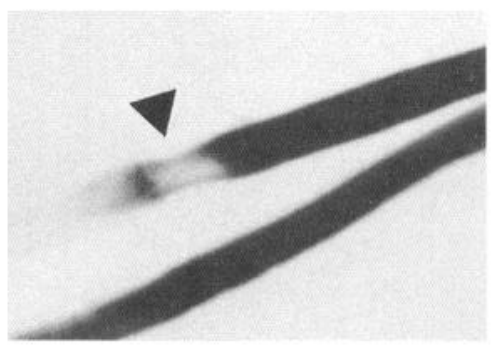

Proximal

Distal

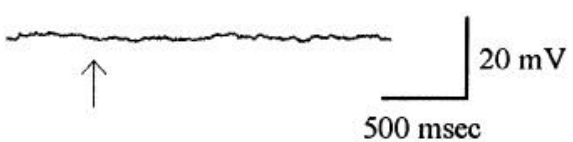

Figure 2. Nerve crush transects all axons and causes loss of evoked responses in siphon motor neurons. Al, A representative photograph showing nickel-lysine staining of a noninjured nerve. Backfilling of noninjured nerves stains axons up to the pleural-pedal ganglia. A2, A representative photograph showing complete transection of axons following nerve crush. One hour after the crush, ganglia were removed and the nerves were cut $4 \mathrm{~cm}$ from the pedal ganglion. The axons were stained using backfilling with nickel lysine. Solid arrow indicates the site of crush. The nickel precipitate stains the portion of the injured nerves distal to the site of crush indicating a complete transection of the axons. The presence of stain visible on the proximal side of the crush is due to transport of stain through the sheath which was not transected during our injury protocol. Although this staining is translucent in nature when visualized under a microscope, the photography makes it appear more opaque. $B 1$, Electrophysiological recording showing the blockade of conduction of action potentials following nerve crush. Pinching noninjured pedal nerve P9, similar to the nerve crush performed during the injury procedure, elicited action potentials in LFS motor neurons. B2, Pinching the same pedal nerve P9 distal to the original crush elicited no action potentials or EPSP indicating that nerve crush effectively transected all axons. Arrows point to the time of nerve pinch.

purified on a $1 \%$ low melting point agarose gel. Approximately $100 \mathrm{ng}$ of the purified cDNA was used to generate a ${ }^{32} \mathrm{P}$-labeled random primed probe for Northern blot analysis using an oligolabeling kit (Pharmacia, Piscataway, NJ). Probes were purified by passage through Sephadex G50 spin columns (Boehringer Mannheim, Indianapolis, IN).

The cDNAs encoding IF protein and calreticulin were isolated using random primed cDNA synthesized from Aplysia whole nervous system and PCR amplification. To amplify the IF protein probe, a sense primer (5'-GCTGCTTTCTACAAGGACCTGTA- $3^{\prime}$ ) corresponding to nucleotides 913-935 and an antisense primer (5'-TTGTTCCATGACGGCTTGCAGCTC-3') complementary to nucleotides 1342-1365 (Reimer et al., 1991) were used. The calreticulin probe was amplified using the sense primer ( $5^{\prime}$-AAAGTTGTTTTACTGTGCGC-3') corresponding to nucleotides 64-83 and the antisense primer (5'-AACTCGTCTTTCTCTGGTGC-3') complementary to nucleotides 1255-1274 (Kennedy et al., 1992). Reverse transcription and PCR amplification were performed using a GeneAmp RNA PCR kit (Perkin Elmer, Norwalk, CT). The IF protein primer was annealed by incubating the mRNA for $1 \mathrm{~min}$ at $50^{\circ} \mathrm{C}$ and the calreticulin primer was annealed for $1 \mathrm{~min}$ at $55^{\circ} \mathrm{C}$. The first cycle of PCR amplification was a $2 \mathrm{~min}$ period at $95^{\circ} \mathrm{C}$. The subsequent 35 cycles were as follows: a $1 \mathrm{~min}$ period at $95^{\circ} \mathrm{C}$ followed by $1 \mathrm{~min}$ at $50^{\circ} \mathrm{C}\left(55^{\circ} \mathrm{C}\right.$ for calreticulin). The last cycle was a $7 \mathrm{~min}$ period at $50^{\circ} \mathrm{C}\left(55^{\circ} \mathrm{C}\right.$ for calreticulin). The reaction products were separated on a $1 \%$ agarose gel. The 452 bp IF protein fragment and 1211 bp calreticulin fragment were cloned into PCR II plasmids (TA cloning system, Invitrogen, San Diego, CA). The ligated plasmids were electroporated into $E$. coli and the bacteria were grown in LB medium. The plasmid DNAs were then isolated using the Midi Prep kit (Qiagen, Chatsworth, CA). The purified plasmid DNA was digested with EcoR1. The inserts were purified on a $1 \%$ low melting agarose gel and the radioactive probes were prepared as described above.

RNA extraction. Total RNA was extracted from the ipsilateral and contralateral pleural or pedal ganglia isolated from the animals used for behavioral measurements at different time points following injury. The 


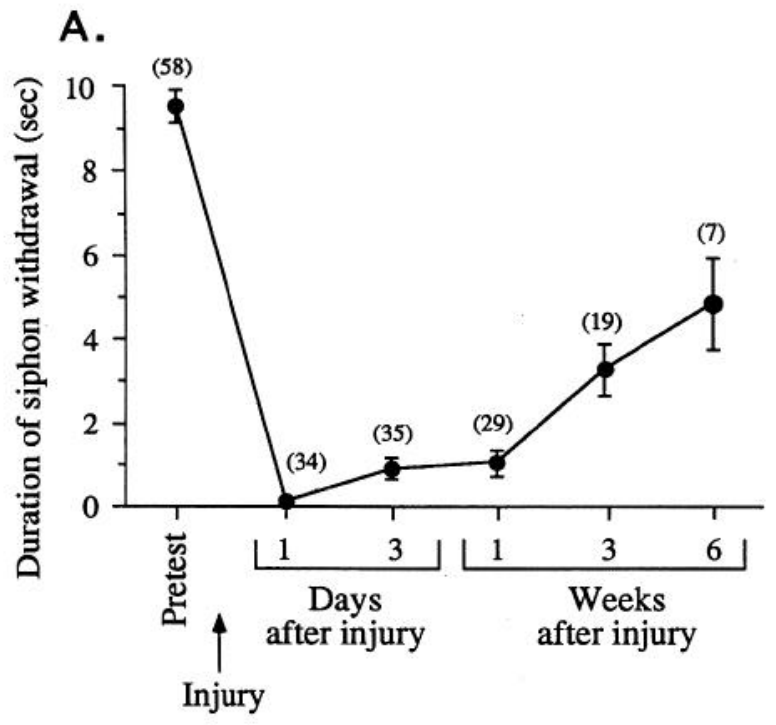

B.

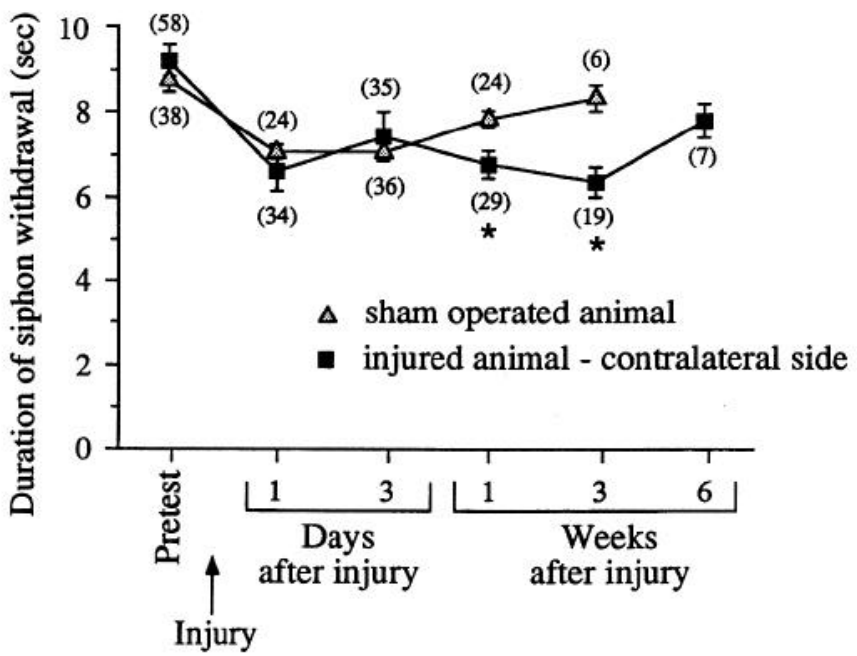

Figure 3. Recovery of the siphon-withdrawal reflex following unilateral axonal injury. A test electrical stimulus was applied to the ipsilateral or contralateral side of the body wall to elicit siphon withdrawal as described in the Methods section. Animals were pretested for siphon withdrawal several hours prior to surgery. $A$, Recovery of the ipsilateral tail-elicited siphon-withdrawal reflex. The ipsilateral reflex gradually recovers and reaches $50 \%$ of the pretest value by 6 weeks post injury. $B$, Inhibition of the tail-elicited siphon-withdrawal reflex as a result of ipsilateral nerve crush. At 1 week and 3 weeks after injury, the duration of siphon withdrawal on the contralateral side was significantly reduced compared to sham operated animals. The numbers in parentheses indicate the number of animals tested at each time point. Statistical significance was determined by Student's $t$ test. *, $p<0.05$.

animals were anesthetized by injection with one-half the body weight of ice-cold isotonic $\mathrm{MgCl}_{2}$. The pleural ganglia from the ipsilateral and contralateral sides were removed and quickly frozen on dry ice. The ganglia from three animals were pooled for each experimental or control sample. Ganglia were homogenized using a hand-held polytron in 0.5 $\mathrm{ml}$ of a prewarmed solution $\left(65^{\circ} \mathrm{C}\right)$ consisting of $0.2 \mathrm{M}$ Tris $\mathrm{pH} 8.2,0.1$ $\mathrm{M} \mathrm{LiCl}, 5 \mathrm{~mm}$ EDTA, $1 \%$ SDS, and $0.5 \mathrm{ml}$ of water saturated phenol (Kennedy et al., 1992). The homogenized samples were incubated on ice for $30 \mathrm{~min}$ and centrifuged at $16,000 \times \mathrm{g}$ for $20 \mathrm{~min}$ at $4^{\circ} \mathrm{C}$. RNA was extracted twice with an equal volume of phenol/chloroform (1:1) and precipitated with ethanol.

Northern hybridization. The concentrations of RNA samples were

\section{A. Nerve Three Days After Injury}

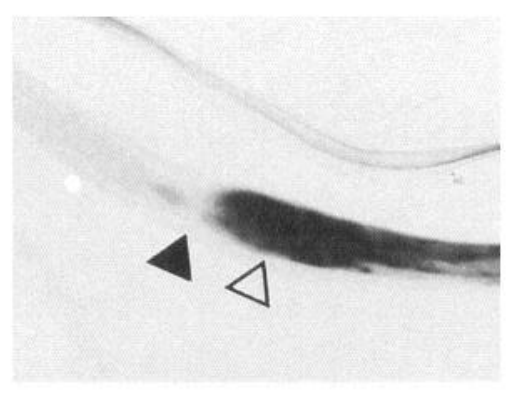

\section{B. Nerve One Week After Injury}

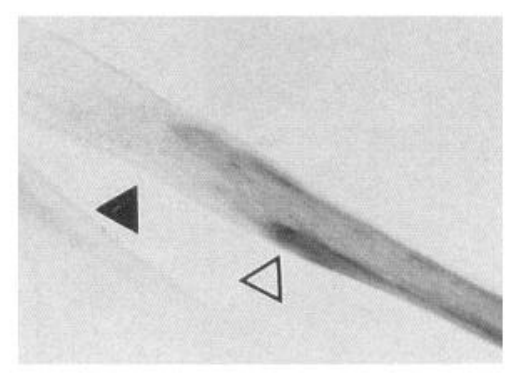

\section{Nerve Three Weeks After Injury}

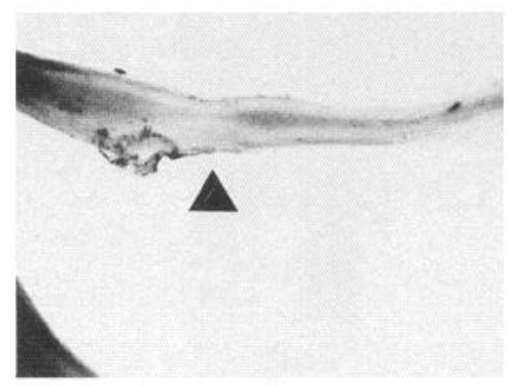

\section{Proximal}

\section{Distal}

Figure 4. Representative photographs showing regeneration of crushed axons. Nerves were cut four centimeters from the pedal ganglia and the axons were stained using backfilling with nickel lysine. $A$ and $B$, Three days and 1 week after injury, nickel precipitate stains only the portion of the injured nerves distal to the site of injury. Solid arrows indicate the site of crush. The dye is distributed in dense patches (open arrows) suggesting degeneration of axons distal to the crush site. $C$, Three weeks after injury, nickel precipitate stains both distal and proximal portions of the injured nerves indicating that axons have grown through the site of crush towards the periphery.

determined by measuring the absorbance at $260 \mathrm{~nm}$. Three micrograms of total RNA from experimental or control samples were separated on a $1 \%$ agarose-formaldehyde gel. The molecular weights of RNAs were determined by running a RNA ladder (Life Technologies, Inc., Gaithersburg, MD) along with RNA from pleural or pedal ganglia. After 1.5 $\mathrm{hr}$ of electrophoresis at $130 \mathrm{mV}$, the gel, stained with ethidium bromide, was photographed to verify equal RNA loading. The RNA was then 


\section{A Tail Innervated by Left and Right Pedal Nerves}

2 Stim. Ipsilateral

Side of Tail

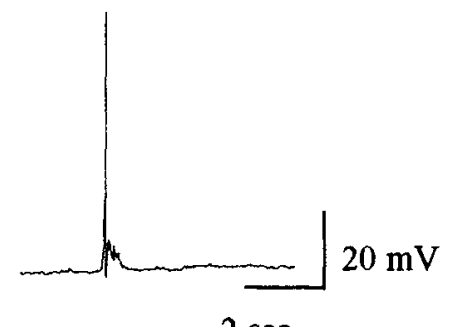

$2 \mathrm{sec}$
B Tail Innervated by Injured P9 Only

\author{
Stim. Ipsilateral \\ Side of Tail
}

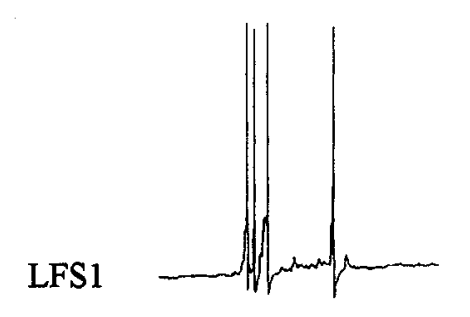

LFS2

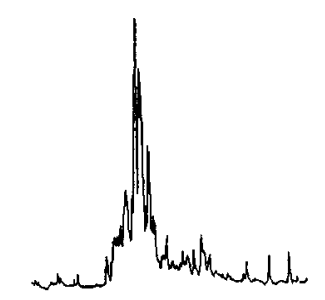

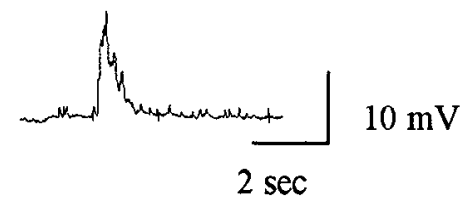

LFS1

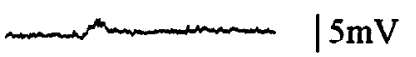

LFS2

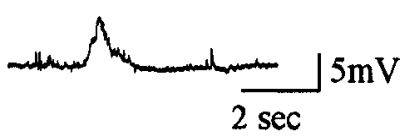

\section{Isolated Nervous System}

1 Stim. of Contralateral P9

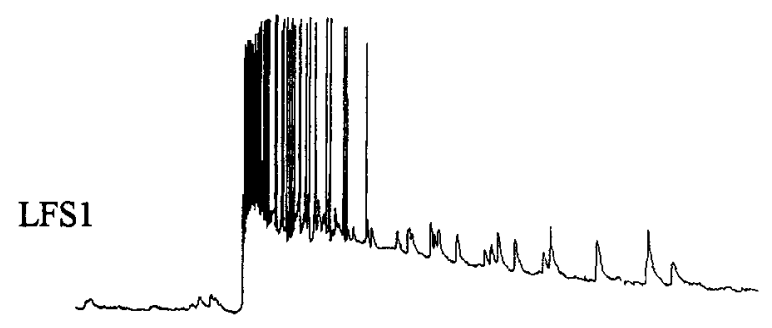

2 Stim. of Ipsilateral P9
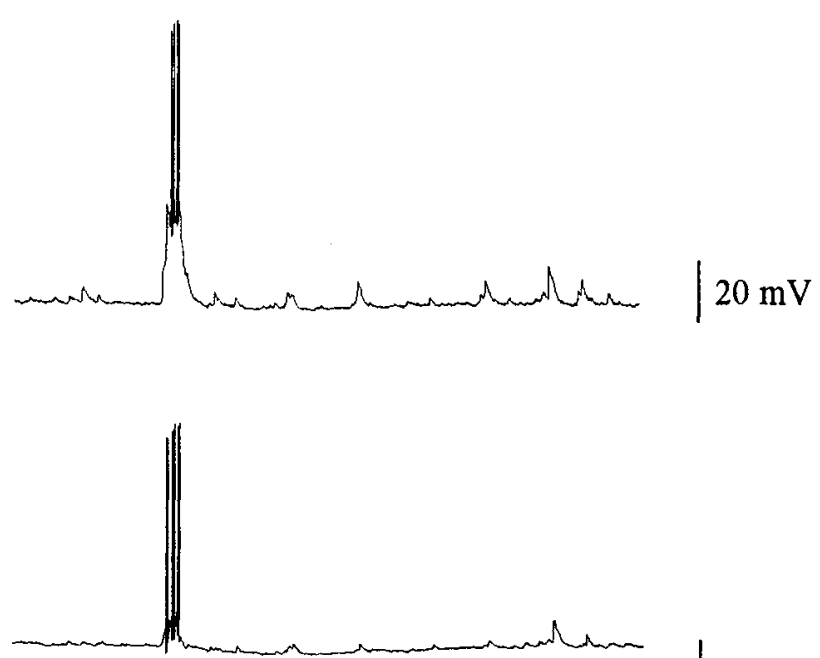

\section{$2 \mathrm{sec}$}

Figure 5. Electrophysiological evidence of axonal regeneration and reinnervation of the tail six weeks after injury. $A$ and $B$, Evidence for reestablishment of functional sensory neuron innervation of the tail. Response of two simultaneously recorded LFS motor neurons to tail stimulation in a semi-intact preparation. Al, Pinch of the side of the tail innervated by uninjured pedal nerves (contralateral side) produced firing of a motor neuron left at resting potential (upper trace), and strong synaptic input in a second motor neuron hyperpolarized below resting potential (lower trace). $A 2$, Pinch of the side of the tail which had its pedal nerve crushed 6 weeks previously also produced a motor neuron response. $B$, Response of the same LFS neurons to ipsilateral tail pinch when all nerves except the injured P9 nerve had been cut. $C$, Evidence for axonal regeneration in preparations which failed to show LFS responses to pinch of the ipsilateral side of the tail. This experiment was carried out using an isolated 
transferred onto a Duralose-UV membrane (Stratagene, La Jolla, CA). The RNA was then cross-linked to the membrane by UV inadiation (Stratalinker, Stratagene, La Jolla, CA). Membranes were prehybridized at $42^{\circ} \mathrm{C}$ for $3 \mathrm{hr}$ in $50 \%$ formamide, $6 \times \mathrm{SSC}, 5 \times$ Denhardt's solution, $0.1 \%$ SDS, and $100 \mu \mathrm{g} / \mathrm{ml}$ denatured salmon sperm DNA. Denatured ${ }^{32} \mathrm{P}$-labeled probes were added to the prehybridization mixture and incubated overnight at $42^{\circ} \mathrm{C}$. Membranes were washed twice with a $2 \times$ SSC, $1 \%$ SDS solution for $20 \mathrm{~min}$ at room temperature and twice with $1 \times \mathrm{SSC}, 1 \% \mathrm{SDS}$ for $20 \mathrm{~min}$ at $65^{\circ} \mathrm{C}$. Membranes were then placed on $x$-ray films (X-OMAT AR, Kodak, Rochester, NY). Films were exposed to membranes for different durations to insure linearity of the optical densities (OD). To remove the probe, membranes were boiled in water for $15 \mathrm{~min}$. The membranes were then placed against $\mathrm{x}$-ray films to verify the complete removal of the probe prior to reuse.

Quantification. The ODs of mRNA bands on autoradiograms were measured using a two-dimensional computerized image analysis system (Bio-Rad Laboratories, Hercules, CA). Integrated ODs of mRNA bands from injured, sham and naive samples were computed. RNA extracted from naive animals was processed on the same blot along with the sham and injured samples. Ganglia from three animals were pooled for each of the injured, sham or naive samples. Three to six experiments were performed at each time point. A paired, two-tailed $t$ test was performed to determine whether the injured and sham ODs were significantly different from the matched naive ODs. A probahility $(p)$ of less than 0.05 was considered significant.

Immunocytochemistry. Pleural-pedal ganglia were fixed in $4 \%$ paraformaldehyde, $15 \%$ picric acid in phosphate buffered saline (PBS) at room temperature for $12 \mathrm{hr}$, and then equilibrated with $30 \%$ sucrose in fixative solution at $4^{\circ} \mathrm{C}$ overnight. Tissue was embedded in OCT compound (Miles Inc., Elkhart, IN), $40 \mu \mathrm{m}$ slices were made on a cryostat and mounted on slides. Slides were incubated with FMRFamide polyclonal antibody (1:500 dilution) (INCSTAR, Stillwater, MN) in 2\% BSA, $0.3 \%$ Triton X-100 in PBS at $4^{\circ} \mathrm{C}$ overnight. Primary antibody was detected using a peroxidase $\mathrm{ABC}$ detection kit followed by $\mathrm{DAB}$ color reaction (Vector Laboratories, Burlingame, CA). Control experiments were performed in the absence of primary antibody to determine the background staining.

\section{Results}

Unilateral nerve crush transects all axons and causes loss of the ipsilateral tail-elicited siphon-withdrawal reflex. In order to determine that the nerve crush procedure completely severed all axons, peripheral pedal nerves were cut four centimeters from the pedal ganglion and backfilled with nickel-lysine for $24 \mathrm{hr}$. In intact nerves, the retrograde transport of nickel-lysine revealed axons which were stained with black-blue nickel precipitate (Fig. 2A) up to and including the cell bodies. The crushed pedal nerves, with the backfill starting $1 \mathrm{hr}$ after injury, showed black-blue nickel precipitate on the distal portion of the pedal nerve up to the distal margin of the crush site. No staining was present in the portion of the nerve proximal to the crush site ( $n$ $=5$ ). There was no difference in staining between the fibers in the contralateral nerves, which had not been injured, and the fibers distal to the crush site in injured, ipsilateral nerves.

To confirm that the nerve crush technique used in our study effectively blocked conduction of action potentials, recordings were made from LFS siphon motor neurons in the abdominal ganglion. In these experiments an uninjured nerve was acutely crushed twice. The first crush always elicited a significant response in the LFS neurons (Fig. 2BI). If the second crush was placed proximal to the first one, another LFS response occurred. If it was placed distal to the first crush, the LFS neuron received no input (Fig. 2B2). This result indicates that nerve crush pro- cedure used to produce injury in this study was effective in transected all axons in the injured nerves and effectively blocked impulse conduction through the crush site. In one separate experiment (not shown) we attached suction electrodes to each end of an isolated nerve stump, which allowed us to stimulate one end and record from the other. We found that our nerve crush procedure completely eliminated the propagation of action potentials from one end of the nerve to the other.

In each, animal the effect of the nerve crush procedure on the tail-elicited siphon withdrawal reflex was tested $24 \mathrm{hr}$ after nerve injury by electrically stimulating the ipsilateral (injured) and contralateral (noninjured) side of the tail and body wall. We found that ipsilateral stimulation produced no measurable siphon withdrawal, whereas contralateral stimulation elicited a withdrawal (Fig. 3A). As previously observed by Jahan-Parwar and Fredman (1978), the injured animals showed contracted body wall and parapodia on the injured side possibly due to loss of tonic inhibition. The contralateral side was not visibly affected by the nerve injury.

Recovery of the tail-elicited siphon-withdrawal reflex. In order to monitor recovery of the reflex, animals were tested at five time points from day 1 to 6 weeks after injury (Fig. 3A). On day 1 , the test stimulus applied on the ipsilateral side of the body wall produced no siphon withdrawal. By day 3 , the ipsilateral tail-elicited siphon-withdrawal reflex recovered to approximately $9 \%$ of the pretest value [duration of siphon withdrawal $(\mathrm{sec} \pm \mathrm{SEM})$ pretest $=9.4 \pm 0.38$, on day $3=0.9 \pm$ $0.25]$. The reflex continued to recover with time, reaching approximately 11,29 and $50 \%$ of the pretest value at 1,3, and 6 weeks, respectively. These results indicate a steady progressive recovery of the tail-elicited siphon withdrawal reflex with time after nerve injury.

The behavioral data from sham-operated animals and contralaterally stimulated injured animals revealed evidence for an inhibition of the reflex (Fig. $3 B$ ). On day 1 after injury, a $30 \%$ reduction of the reflex was observed in both sham operated and contralaterally stimulated animals. In order to determine if the reduction of the reflex was caused either by surgery or by habituation to the test stimulus, naive animals were subjected to the testing protocol. These animals did not show a significant reduction in the duration of the siphon-withdrawal reflex to the test stimulus [duration of siphon withdrawal (sec \pm SEM) pretest $=7.3 \pm 0.31$, on day $1=7.36 \pm 0.48, n=10]$. This indicates that the surgery procedure itself causes a transient inhibition of the reflex. However, we observed a persistent reduction in the contralateral reflex response at 1 week and 3 weeks after injury as compared to sham operated animals [duration of siphon withdrawal (sec) \pm SEM, 1 week after injury: contralateral side $=6.8 \pm 0.34$, sham operated $=7.8 \pm 0.18, p<0.01$; 3 weeks after injury: contralateral side $=6.3 \pm 0.36$, sham operated $=8.3 \pm 0.30, p<0.01]$. This result indicates that unilateral injury causes a delayed reduction of siphon-withdrawal reflex on the noninjured side of the animal which is not solely due to the surgery procedure.

Functional recovery of neural pathways involved in siphon withdrawal. In order to determine the time course of axonal

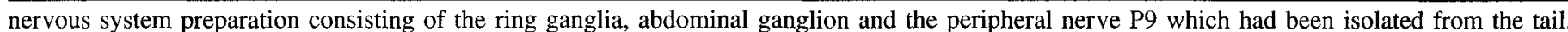

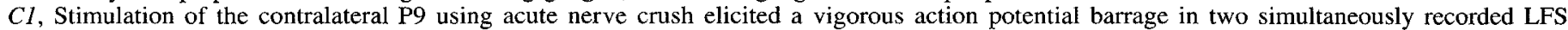
neurons. $C 2$, Stimulation of the ipsilateral $P 9$ distal to the injury site also produced a response, although much weaker in intensity. 
Table 1. Summary of changes in expression of specific mRNAs following axonal injury

\begin{tabular}{llll} 
& $\begin{array}{l}\text { Ipsi- } \\
\text { lateral } \\
\text { pleural } \\
\text { ganglia }\end{array}$ & $\begin{array}{l}\text { Contra- } \\
\text { lateral } \\
\text { pleural } \\
\text { ganglia }\end{array}$ & Function \\
\hline Actin & ++ & + & Neurite growth and synapse formation ${ }^{a}$ \\
IF protein & - & $\mathrm{nc}$ & Cytoskeletal function and axonal caliber \\
Calreticulin & + & $\mathrm{nc}$ & Calcium buffering and modulator of transcription \\
Sensorin A & - & $\mathrm{nc}$ & Neuromodulator, synthesized in sensory neurons \\
FMRFamide & - & + & Inhibitory neuromodulator
\end{tabular}

Data present a summary of the injury-related changes in mRNA expression in the pleural ganglia following unilateral nerve injury. Northern blot analysis showed changes in mRNA expression of two structural proteins, actin and IF protein, of a calcium binding protein, calreticulin, and of two neuropeptides, sensorin A and FMRFamide. Changes were observed in both ipsi- and contralateral pleural ganglia. + , increased expression relative to naive or shamoperater animals; - decreased expression relative to naive or sham-operated animals; nc, no change in expression relative to naive or sham-operated animals.

${ }^{a}$ Smith, 1988.

${ }^{b}$ Hoffman et al., 1987; Lasek et al., 1983.

'Smith and Koch, 1989; Opas et al., 1991; Burns et al., 1994; Dedhar et al., 1994.

${ }^{d}$ Brunet et al., 1991.

' Abrams et al., 1984; Brezina et al., 1987; Dale and Kandel, 1990; Pieroni and Byrne, 1992.

regeneration through the sites of injury, peripheral pedal nerves were cut $4 \mathrm{~cm}$ from the pedal ganglion, distal to the injury sites, and backfilled with nickel-lysine. This was done $3 \mathrm{~d}, 1$ week, and 3 weeks following injury. Nerves stained $3 \mathrm{~d}$ (Fig. $4 A$ ) or 1 week (Fig. $4 B$ ) after injury showed black-blue nickel precipitate up to but not across the crush site. This result indicates that during the first week following injury no axons had regenerated through the injury sites. The nickel precipitate distal to the crush site was distributed in dense patches (Fig. 4A,B), suggesting degeneration of these isolated axon stumps. In nerves stained 3 weeks after injury, the nickel precipitate was present in axons on both sides of the pedal nerve crush site (Fig. $4 C^{\prime}$ ). These results indicate that by three weeks some axons had regenerated through the sites of injury and at least $4 \mathrm{~cm}$ down the injurcd nerves. While this provided evidence for axonal regeneration from the pleural ganglion toward the tail, it did not distinguish between sensory and motor neuron processes, nor did it determine whether any of those processes had reestablished connections with the tail.

To determine whether regenerating sensory neuron axons had functionally reinnervated the tail, we recorded the response of the LFS cells to tail pinch. All animals used in the electrophysiological experiments displayed recovery of the ipsilateral siphon-withdrawal reflex. Animals were tested 3 weeks after injury $(n=4)$ and 6 weeks after injury $(n=5)$. When innervated by both left and right pedal nerves, pinching either side of the tail produced LFS input in all preparations (Fig. $5 \mathrm{~A}$ ). In one out of four preparations 3 weeks after injury and in three out of five preparations 6 weeks after injury, tail pinch produced input to the LFS cells when only the injured P9 remained (Fig. 5B). Since in this case the only route to the LFS cells was through the site of previous nerve transection, this suggests that sensory neuron axons had regenerated all the way to the tail and had reestablished functional afferent connectivity.

Animals that did not show any response to ipsilateral tail pinch had either regenerating axons that did not reach the tail, or axons that failed to regenerate. In order to distinguish between these possibilities we recorded the firing response of the LFS motor neurons to acute pedal nerve crushes. Crushing the undamaged contralateral P9 always elicited a barrage of action potentials in the LFS cells (Fig. $5 \mathrm{Cl}$ ). On the ipsilateral side, crushing the damaged $\mathrm{P} 9$ in a corresponding location, distal to the injury scar, also elicited an LFS response (Fig. 5C2). Since in these injured nerves the only route to the LFS cells was through the site of crush, regeneration of electrically functional axons through the sites of nerve transection must have occurred. However, at both 3 weeks and 6 weeks after injury, the number of spikes in every case was less on the injured side than on the noninjured side (average number of spikes 3 weeks after injury, noninjured P9 nerve pinch $=49$, injured $\mathrm{P} 9$ nerve pinch $=13$; 6 weeks after injury: noninjured P9 nerve pinch $=65$, injured P9 nerve pinch $=8$ ).

Changes in the expression of specific mRNAs are detected in both the ipsi- and contralateral pleural ganglia following axonal injury. The behavioral, morphological and electrophysiological studies described above suggest that following nerve injury significant axonal growth leads to partial recovery of the siphonwithdrawal reflex. Presumably, this growth process would require enhanced expression of structural genes as well as other genes involved in neuronal function. We have investigated the changes in the level of mRNA coding for actin, IF protein, calreticulin, sensorin A, and FMRFamide. Northern blot analysis was performed using RNA extracted from naive, sham and both the ipsi- and contralateral pleural ganglia from injured animals. The ipsilateral pleural ganglia contain the sensory neurons that were axotomized by the injury procedure. However, we cannot localize the molecular changes to sensory neurons since mRNA was isolated from a population of cells containing sensory neurons, motor neurons, interneurons and glial cells. A summary of the changes in the expression of mRNA of the above mentioned genes is outlined in Table 1.

Changes in the levels of actin, IF protein, calreticulin, sensorin A, and FMRFamide mRNA in the ipsilateral pleural ganglia. The level of actin mR.NA was significantly increased compared to naive animals three days and one week after injury (percent change from naive $\pm \mathrm{SEM}=201 \pm 49, p<0.05, n$ $=5$ and $259 \pm 85, p<0.01, n=5$, respectively) (Fig. $6 B$ ). The mRNA levels were not significantly different from naive value by 3 weeks after injury. Northern blots using an Aplysia IF protein probe revealed three bands, that migrate close to the 


\section{A. Actin mRNA}
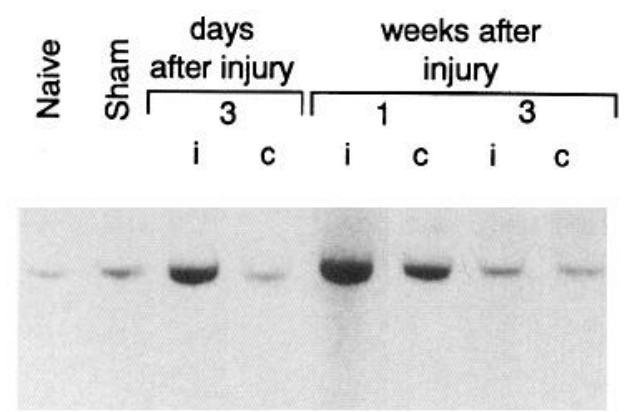

B. Actin mRNA
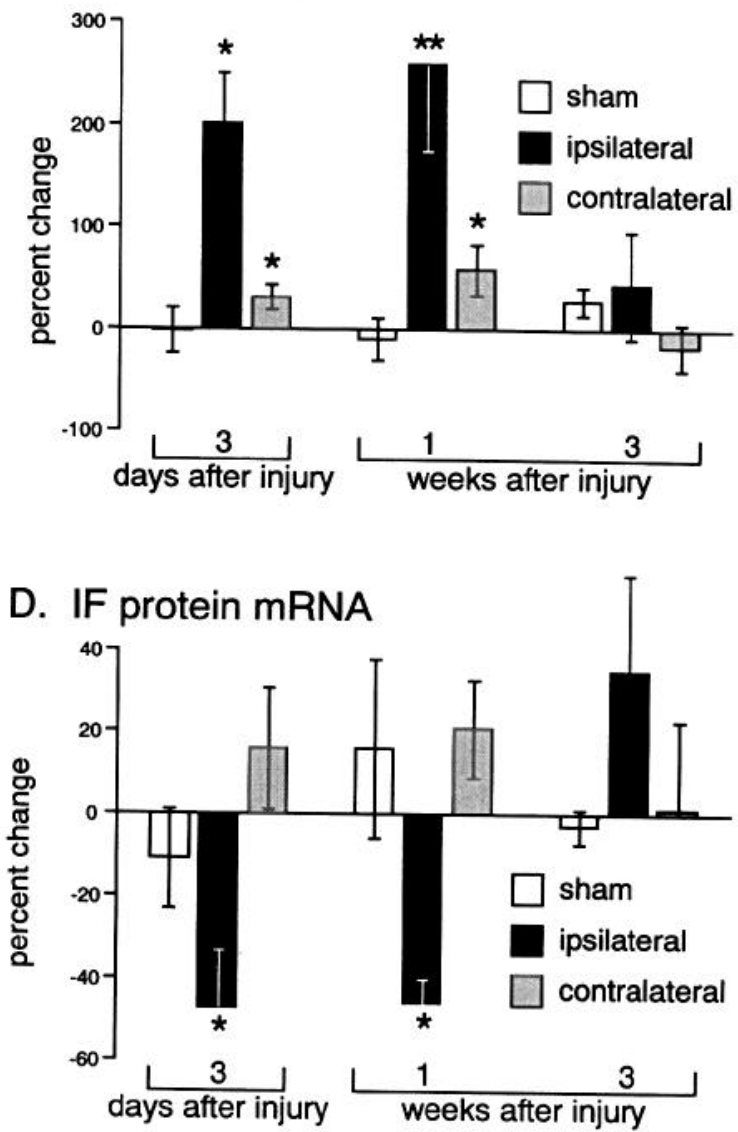

Figure 6. Changes in the levels of mRNA coding for actin and IF protein in pleural ganglia following axonal injury. A, Picture of a representative Northern blot using the Aplysia actin cDNA probe showing the changes in the level of the $1.6 \mathrm{~kb}$ actin mRNA over time (DesGroseillers et al, 1994). The sham operated animals were sacrificed 1 week after the surgery. $B$, Summary of the changes in actin mRNA expressed as percent change \pm SEM relative to the naive animals. $C$, Picture of a representative Northern blot using the Aplysia IF protein cDNA probe showing the changes in the level of the $4.4 \mathrm{~kb}$ IF protein mRNAs over time. The sham mRNA shown is from animals sacrificed 1 week after the surgery. $D$, Summary of the changes in IF protein mRNAs expressed as percent change \pm SEM relative to the naive animals. Ipsilateral $(i)$, contralateral $(c)$. Paired $t$ tests were performed between the experimental ODs and the matched control ODs. *, $p<0.05 ; * *, p<0.01$.

$4.4 \mathrm{~kb}$ marker, whose optical densities were combined for analysis (Fig. $6 C$ ). The level of mRNA was significantly decreased in the ipsilateral ganglia $3 \mathrm{~d}$ and 1 week after injury (percent change from naive $\pm \mathrm{SEM}=-47 \pm 14, p<0.05, n=4$ and $-46 \pm 6, p<0.05, n=4$ respectively) (Fig. $6 D$ ). Three weeks after injury, IF protein mRNA was not significantly different from control levels. The level of calreticulin mRNA was significantly increased 1 week after injury (percent change from naive $\pm \mathrm{SEM}=80 \pm 22, p<0.05, n=6$ ) (Fig. 7B). The level of sensorin A mRNA was significantly decreased 1 week after injury (percent change from naive \pm SEM $=-65 \pm 9, p<0.05$, $n=4$ ) (Fig. $8 B$ ) while the sham operated animals at the same time point showed a significant increase in sensorin A mRNA. The level of FMRFamide mRNA was significantly decreased 1 week after injury (percent change from naive \pm SEM $=-55$ $\pm 13, p<0.05, n=4$ ) (Fig. 8D). The levels of sensorin A and FMRFamide mRNAs were reliably decreased 3 weeks after injury, although not statistically significant.

Changes in the levels of actin, IF protein, calreticulin, sensorin A, and FMRFamide mRNA in the contralateral pleural ganglia. Similar to the ipsilateral side, the actin mRNA was significantly increased $3 \mathrm{~d}$ and 1 week after injury (percent change from naive $\pm \mathrm{SEM}=31 \pm 12, p<0.05, n=5$ and
$59 \pm 25, p<0.05, n=5$, respectively) (Fig. 6A,B). However, unlike the ipsilateral pleural ganglia, sensorin A mRNA level was significantly enhanced three days after injury (percent change from naive $\pm \mathrm{SEM}=58 \pm 23, p<0.05, n=4$ ) while FMRFamide mRNA was increased one week after injury (percent change from naive $=136 \pm 62, p<0.05, n=4$ ). There was no significant change in IF protein or calreticulin mRNA as compared to naive.

Changes in the levels of actin, IF protein and calreticulin mRNAs were unaffected in sham operated animals. Sensorin A showed a significant increase in mRNA level 1 week after injury (percent change from naive $\pm \mathrm{SEM}=46 \pm 12, p<0.05, n=$ 4) (Fig. $8 B$ ) and FMRFamide was significant decreased $3 \mathrm{~d}$ after injury (percent change from naive $\pm \mathrm{SEM}=-59 \pm 17, p<$ $0.05, n=4$ ) (Fig. $8 D$ ).

FMRFamide immunoreactivity was increased in contralateral pleural-pedal ganglia. We next examined whether the increase in the amount of FMRFamide mRNA was associated with an increase in the level of FMRFamide peptide. Slices of pleuralpedal ganglia from injured and naive animals were stained using a polyclonal FMRFamide antibody. This antibody has previously been used to localize FMRFamide in an inhibitory neuron in Aplysia (Xu et al., 1994). The antibody stained cell bodies and 


\section{A. Calreticulin mRNA}<smiles>[CH]C=C</smiles>

B. Calreticulin mRNA

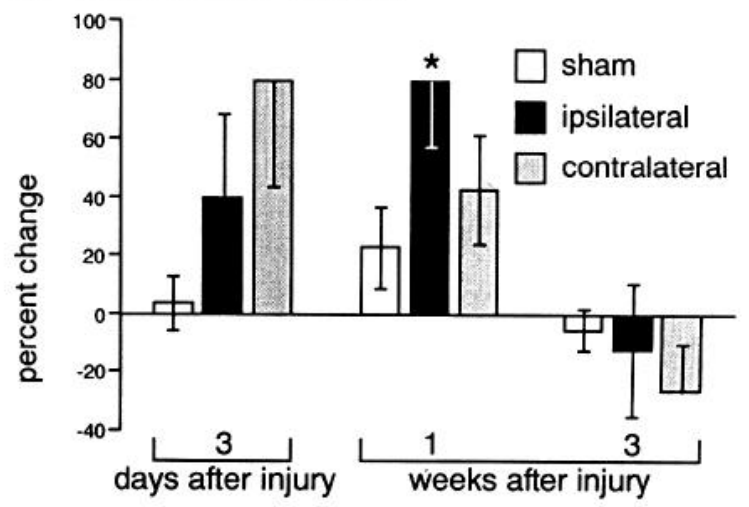

Figure 7. Changes in the levels of mRNA coding for calreticulin in pleural ganglia following axonal injury. A, Picture of a representative Northern blot using the Aplysia calreticulin cDNA probe showing the changes in the level of the $1.8 \mathrm{~kb}$ calreticulin mRNA over time (Kennedy et al., 1992). Sham mRNA shown is from animals sacrificed 1 week after the surgery. $B$, Summary of the changes in the calreticulin mRNA expressed as percent change \pm SEM relative to the naive animals. Ipsilateral $(i)$, contralateral $(c)$. Paired $t$ tests were performed between the experimental ODs and the matched control ODs. ${ }^{*}, p<0.05$.

\section{A. Sensorin A mRNA}
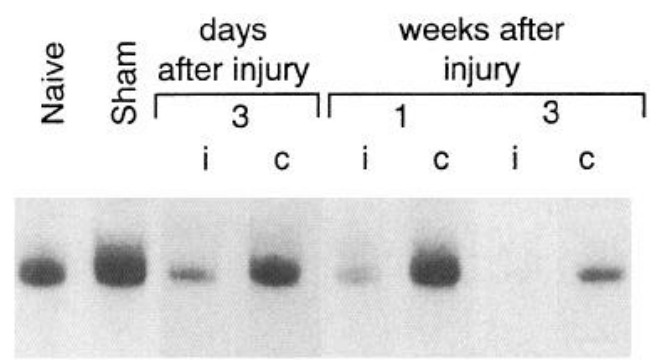

B. Sensorin A mRNA

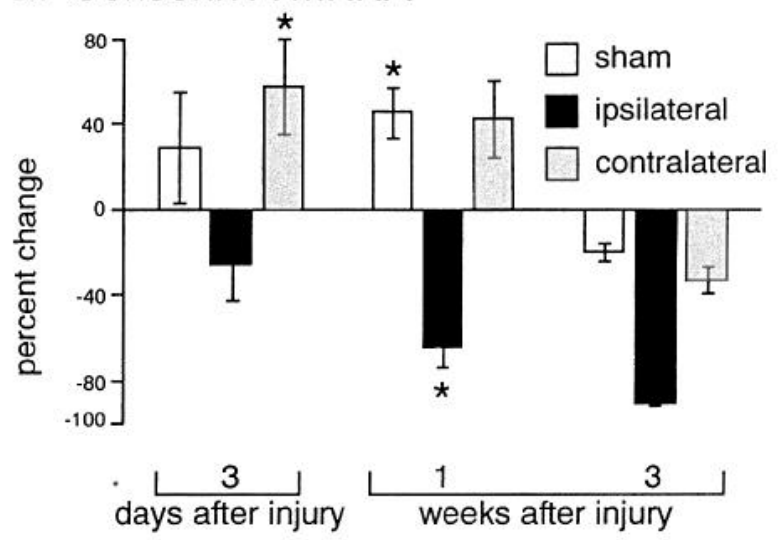

\section{FMRFamide mRNA}
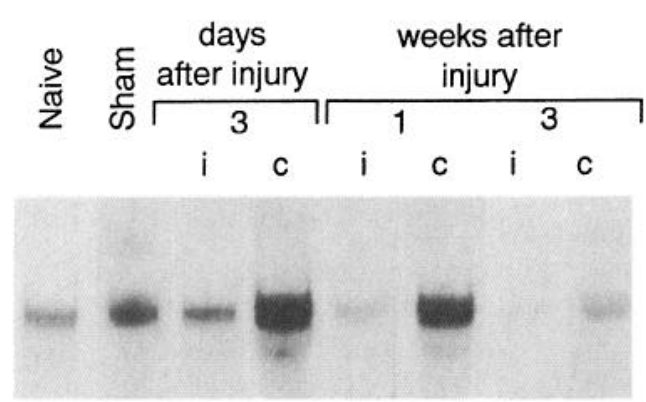

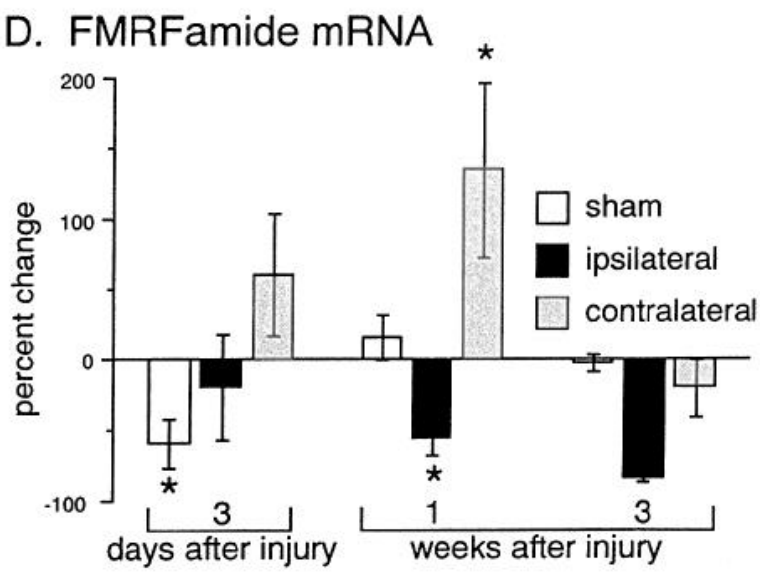

Figure 8. Changes in the levels of mRNA coding for sensorin A and FMRFamide peptides in pleural ganglia following axonal injury. A, Picture of a representative Northern blot using the sensorin A cDNA probe showing the changes in the level of thc $0.7 \mathrm{~kb}$ sensorin A mRNA over time (Brunet et al., 1991). Sham mRNA shown is from animals sacrificed 1 week after the surgery. B, Summary of the changes in sensorin A mRNA expressed as percent change \pm SEM relative to the naive animals. $C$, Picture of a representative Northern blot using the FMRFamide peptides cDNA probe showing the changes in the level of the $2.3 \mathrm{~kb}$ FMRFamide peptides mRNA over time. Sham mRNA shown is from animals sacrificed 1 week after the surgery. $D$, Summary of the changes in FMRFamide peptide mRNA expressed as percent change \pm SEM relative to the naive animals. Ipsilateral $(i)$, contralateral $(c)$. Paired $t$ tests were performed between the experimental ODs and the matched control ODs. $*, p<0.05$. 


\section{FMRFamide Immunoreactivity in the Pleural and Pedal Ganglia One Week After Unilateral Nerve Crush}

A. Non-Injured

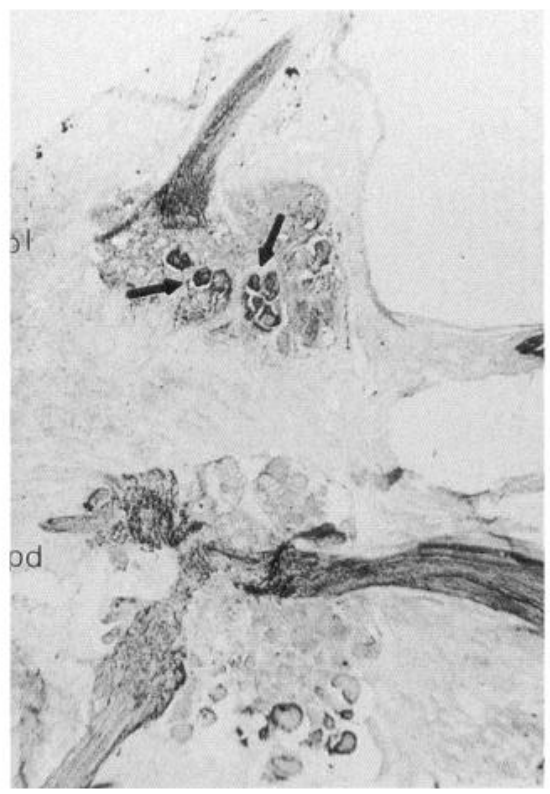

B. Ipsilateral

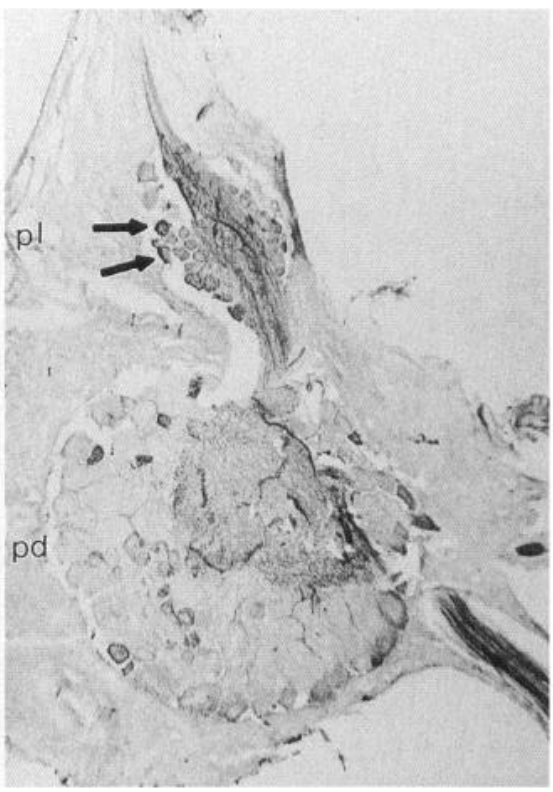

C. Contralateral

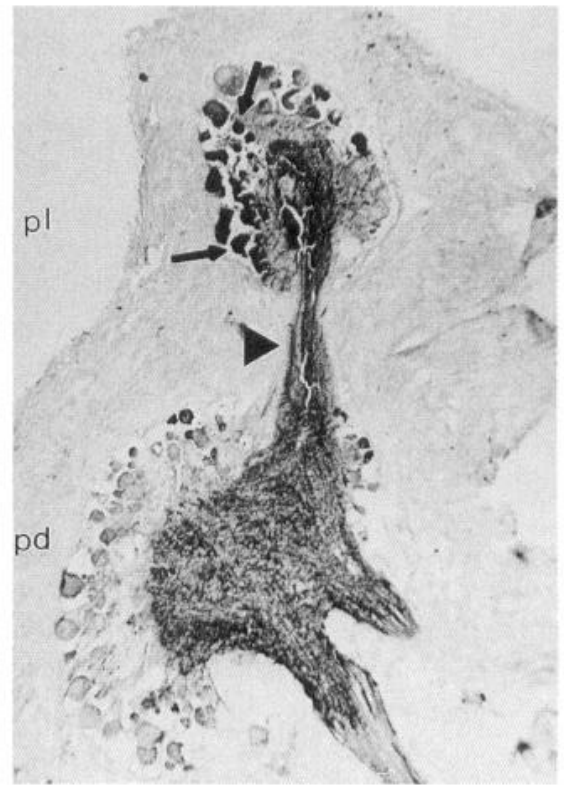

Figure 9. Immunostaining of the pleural $(p l)$ and pedal $(p d)$ ganglia with an antibody specific for the FMRFamide peptides 1 week after unilateral nerve crush. $A$, Section from a pleural-pedal ganglia from a naive animal showing the basal level of FMRFamide immunoreactivity. $B$, Section from an ipsilateral pleural-pedal ganglia from an animal 1 week after the injury procedure. $C$, Section from a contralateral pleural-pedal ganglia from the same animal showing increased immunoreactivity. Arrows indicate selective immunopositive cells in the pleural ganglion, arrowhead points to neuropil.

the pleural and pedal neuropils. One week after injury, the contralateral ganglia (Fig. 9C) showed stronger immunoreactivity compared to the ipsilateral (Fig. $9 B$ ) or naive ganglia (Fig. 9A). It is difficult to identify if the same cells shown in Figure $9 A$ have enhanced staining in Figure $9 C$. However, comparing the staining in the neuropil revealed qualitatively similar changes as detected by Northern blots. In control experiments, no immunoreactivity was detected when the primary antibody was omitted from the incubation solution.

\section{Discussion}

Unilateral axonal injury triggers cellular and molecular changes not only in the injured neurons but often in the contralateral noninjured neurons (Gunning et al., 1977; Herrera and Grinnel, 1981; Stodieck et al., 1986). In this study we present evidence to show that axonal regeneration and recovery of the tail-elicited siphon-withdrawal reflex following unilateral nerve crush in Aplysia californica are concurrent with molecular changes in both the ipsi- and contralateral ganglia. We found that unilateral nerve crush caused an immediate loss of the ipsilateral siphonwithdrawal reflex while the contralateral reflex was not different from sham operated animals. The siphon-withdrawal reflex partially recovered within three days and progressively increased to approximately $50 \%$ of the pretest value by 6 weeks after injury. We have not followed the behavioral recovery beyond 6 weeks and thus cannot ascertain if the reflex will ever fully recover to the preinjury value. A faster recovery of the siphon-withdrawal reflex following pedal nerve crush was reported by Dulin et al. (1995). The injury procedure and behavioral assessment used in our study were different from that of Dulin et al. which could explain the apparent discrepancy between the two studies.

We measured the duration of siphon-withdrawal which allowed us to observe a gradual recovery of the reflex. At $3 \mathrm{~d}$ and 1 week after injury, the reflex recovered to $9 \%$ and $11 \%$ of the pretest value, respectively. However, using retrograde staining of axons with nickel-lysine, we failed to detect any regenerating axons through the injured nerves at these two time points. At 3 and 6 weeks after injury, the reflex recovers to $29 \%$ and $50 \%$, respectively. At these later time points, retrograde staining showed regeneration of axons in the injured nerves. Moreover, stimulation of the distal portion of injured pedal nerve P9 induced EPSPs and action potentials in LFS siphon motor neurons. Every animal used in electrophysiological experiments showed complete inhibition of the reflex on day 1 after injury and partial recovery of the reflex at the time of the experiment ( 3 weeks or 6 weeks after injury). However, only one out of four animals at 3 weeks and three out of five animals at 6 weeks after injury showed reestablishment of functional connections of the injured pedal nerves to the ipsilateral tail. These findings suggest that in addition to the regenerating nerves, another neuronal pathway(s) participates in the early recovery of the reflex. For example, the central siphon sensory neurons could sprout and send neurites to the tail region. A tail stimulation could thereby activate LFS motor neurons and elicit siphon withdrawal without 
involvement of the regenerated peripheral nerve pathway. We find this possibility unlikely because when the siphon was surgically isolated from the tail, we were still able to record a response to tail pinch. In addition, peripheral neurons have been reported to contribute to the siphon-withdrawal reflex (Bailey et al., 1979). Sprouting of peripheral sensory neurons in the tail or nearby regions could also participate in the gradual recovery of the reflex. Such sprouting could explain the recovery at early time points. Finally, it has been observed that the sensory neuron receptive fields sometimes expand from the contralateral side of the tail following deep incision injury of the tail and body wall (Billy and Walters, 1989). Unilateral injury to the entorhinal cortex in rats is followed by sprouting from the uninjured side to the ipsilateral hippocampus (Steward et al., 1973). This is accompanied by recovery of a spatial behavioral task, spontaneous alternation (Scheff and Cotman, 1977). Part of the recovery observed in our preparation may have been mediated by a similar mechanism. This hypothesis is supported by the observation that transection of contralateral pedal nerve P9 eliminated action potentials that were elicited by ipsilateral tail pinch $(75 \%$ of animals at 3 weeks and $40 \%$ of animals at 6 weeks). This is further supported by the observed changes in mRNA levels in the contralateral pleural ganglia.

Injury to neurons leads to alterations of structural protein expression that are thought to be molecular correlates of axonal growth (for review see Skene, 1989). The increase in actin expression in both the ipsi- and contralateral sides may participate in axonal regeneration and/or sprouting. The level of Aplysia IF protein mRNA is decreased following injury and returns to control level by 3 weeks in the ipsilateral pleural ganglia. The downregulation of neurofilaments has been shown to lead to a decrease in axonal caliber, an event associated with axonal elongation (Lasek et al., 1983; Hoffman et al., 1987; Oblinger et al., 1989).

Calreticulin is a major calcium binding protein, located predominantly in the lumen of the endoplasmic reticulum where it is thought to act as an intracellular calcium buffer (Smith and Koch, 1989). Recently, it has been reported that calreticulin is also localized in the nucleus (Opas et al., 1991) and modulates steroid-mediated gene transcription (Burns et al., 1994; Dedhar et al., 1994). The expression of calreticulin has also been observed to be enhanced in pleural sensory neurons following long-term sensitization in Aplysia, a process associated with sprouting of the sensory neuron terminals (Kennedy et al., 1992). The increased expression of calreticulin following axonal injury may take part in calcium buffering and/or control of gene transcription.

The levels of mRNAs coding for two neuropeptides, sensorin $A$ and FMRFamide, in the ipsilateral pleural ganglia were decreased for at least three weeks following the crush. The significance of this decrease is not known at present. The loss of synaptic targets of axotomized pleural sensory neurons might lead to a decrease in synthesis of neurotransmitters as previously described in mammals (Koo et al., 1988). The injury protocol disrupted the synaptic connection between sensory neurons and their follower cells as well as the sensory neuron sites of peripheral innervation. Thus, the loss of sensory neuron targets may downregulate the expression of sensorin A and FMRFamide. The decrease in expression of these inhibitory neuropeptides in the ipsilateral pleural ganglia could contribute to the increased excitability of axotomized mechanosensory neurons and in- creased synaptic connection with motor neurons (Walters et al., 1991; Clatworthy and Walters, 1994).

An increase in sensorin A mRNA was seen in both the contralateral and sham operated pleural ganglia between three days and one week. This enhanced expression in the contralateral and sham operated animals could contribute to the early inhibition of the siphon-withdrawal reflex. However, due to the fact that the naive animals were not subjected to the test stimuli, this enhanced expression could result from the surgery and/or the behavioral tests. The amount of FMRFamide as detected both by Northern blotting and immunohistochemistry is also increased in the contralateral ganglia and neuropil as early as one week following injury. This increase was not observed in sham operated animals. Transmitter-mediated inhibition of the siphonelicited siphon-withdrawal reflex has been previously observed (Fitzgerald and Carew, 1991; Wright et al., 1991), and it is possible that the overexpression of FMRFamide could contribute to the delayed inhibition of the contralateral tail-elicited siphonwithdrawal reflex.

Similar to the changes seen in the ipsilateral pleural ganglia, our preliminary studies indicate that actin and calreticulin mRNA levels were increased and $\mathrm{IF}$ protein mRNA level was decreased in ipsilateral pedal ganglia. The amount of FMRFamide and sensorin A mRNA in naive animals were too low for analysis. These findings suggest that injury to neurons located either in the pleural or in the pedal ganglia are associated with similar pattern of gene activation.

The signal(s) triggered by the crush that leads to alterations in gene expression and protein synthesis is currently being investigated in several laboratories. The nuclear localization sequence containing protein, $\mathrm{sp} 97$, is identified as a potential retrograde injury signal (Walters and Ambron, 1995). This protein, or yet unidentified proteins, could participate in the ipsilateral changes in gene expression. The induction of contralateral changes in mRNA expression might involve several mechanisms (Rotshenker, 1988). Transynaptic interactions through pedal and pleural-cerebral connectives may lead to changes in gene expression in the contralateral side. Hormones or growth factors released as a result of injury could also produce differential effects on gene expression. Future experiments will help in identifying the signal(s) which leads to the differential patterns of gene expression following unilateral nerve injury.

It has been hypothesized that axonal injury and 5-HT-induced hiophysical changes may have overlapping mechanism(s) (Walters and Ambron, 1995). The injury-induced changes in calreticulin and actin mRNA levels are consistent with the changes observed following sensitizing treatments (Kennedy et al., 1992; Noel et al., 1993). However, the changes in IF protein mRNA following injury is opposite to the changes in IF protein synthesis following sensitization (Noel et al., 1993). Such discrepancy might indicate that different mechanisms are involved in injuryinduced growth and sensitization-induced growth.

It is interesting to note that increases in excitability is detected in axotomized sensory neurons located in the ipsilateral pleural ganglion but not in nonaxotomized sensory neurons in the contralateral ganglion (Walters et al., 1991). The electrophysiological and molecular data presented in this study suggest that contralateral pleural sensory neurons sprout to the injured side. It is tempting to speculate that increases in excitability are a marker for ncuronal injury on the ipsilateral side and not necessarily indicators of sprouting which may be occurring in the contra- 
lateral side. Future experiments will help delineate between these two processes.

\section{References}

Abrams TW, Castellucci VF, Camardo JS, Kandel ER, Lloyd PE (1984) Two endogenous neuropeptides modulate the gill and siphon withdrawal reflex in Aplysia by presynaptic facilitation involving cAMPdependent closure of a serotonin-sensitive potassium channel. Proc Natl $\Lambda$ cad Sci USA 81:7956-7960.

Aletta JM, Goldberg DJ (1982) Rapid and precise down regulation of fast axonal transport of transmitter in an identified neuron. Science 218:913-916.

Ambron RT, Schmied R, Osipov A (1993) Evidence that the retrograde transport-nuclear import pathway conveys an injury signal after axotomy of Aplysia neurons. Soc Neurosci Abstr 19:1510.

Bailey CH, Castelluci VF, Koester J, Kandel ER (1979) Cellular studies of peripheral neurons in siphon skin of Aplysia californica. J Neurophysiol 42:530-557.

Billy AJ, Walters ET (1989) Long-term expansion and sensitization of mechanosensory receptive fields in Aplysia support an activity-dependent model of whole-cell sensory plasticity. J Neurosci 9:12541262.

Brezina V, Eckert R, Erxleben C (1987) Modulation of potassium conductance by endogenous neuropeptide in neurones of Aplysia californica. J Physiol (Lond) 382:267-290.

Brunet JF, Shapiro E, Foster SA, Kandel ER, Iino Y (1991) Identification of a peptide specific for Aplysia sensory neurons by PCRbased differential screening. Science 252:856-859.

Buriani A, Savage MJ, Burmeister DW, Goldberg DJ (1990) Early changes in nuclear proteins following axotomy. J Neurochem 55: 1817-1820.

Burns K, Duggan B, Atkinson EA, Famulski KS, Nemer M, Bleackley RC, Michalak M (1994) Modulation of gene expression by calreticulin hinding to the glucocorticoid receptor. Nature 367:476-480.

Byrne JH (1987) Cellular analysis of associative learning. Physiol Rey $67: 329-439$.

Carew TJ, Walters ET, Kandel ER (1981) Associative learning in Aplysia: cellular correlates supporting a conditioned fear hypothesis. Science 211:501-504.

Castellucci VF, Kennedy TE, Kandel ER, Goelet P (1988) A quantitative analysis of 2-D gels identifies proteins in which labeling is increased following long-term sensitization in Aplysia. Neuron $4: 321-328$

Clatworthy AL, Walters ET (1994) Comparative analysis of hyperexcitability and synaptic facilitation induced by nerve injury in two populations of mechanosensory neurons of Aplysia californica. J Exp Biol 190:217-238.

Cleary LT, Byrne JH (1993) Identification and characterization of a multifunction neuron contributing to defensive arousal in Aplysia. J. Neurophysiol 70:1767-1776.

Dale N, Kandel ER (1990) Facilitatory and inhibitory transmitters modulate spontaneous transmitter release at cultured Aplysia sensory motor synapses. J Physiol (Lond) 421:203-222

Dedhar S, Renmie PS, Shago M, Hagesteijn CL, Filmus J, Hawley RG, Bruchovsky $\mathrm{N}$, Cheng $\mathrm{H}$, Matusik RJ, Giguère V (1994) Inhibition of nuclear hormone receptor activity by calreticulin. Nature 367:480483.

DesGroseillers L, Auclair D, Wickham L, Maalouf M (1994) A novel actin cDNA is expressed in the neurons of Aplysia californica. Biochem Biophys Acta 1217:322-324.

Dulin MF, Steffensen I, Morris CE, Walters ET (1995) Recovery of function, peripheral sensitization and sensory neuron activation by novel pathways following axonal injury in Aplysia california. J Exp Biol, in press.

Elliot SP, Schmied R, Gabel CA, Ambron RT (1993) An 83 KDa O-GlcNAc-glycoprotein is found in the axoplasm and nucleus of Aplysia neurons. J Neurosci 13:2424-2429.

Filzgerald K, Carew TJ (1991) Serotonin mimics tail shock in producing transient inhibition in the siphon withdrawal reflex of Aplysia. J Neurosci 8:2510-2518.

Fredman SM (1987) Intracellular staining of neurons with nickel-lysine. J Neurosci Methods 20:181-194.

Fredman SM (1988) Recovery of escape locomotion following a CNS lesion in Aplysia. Behav Neural Biol 49:261-279.

Goldsmith JR, Byrne JH (1993) Bag cell extract inhibits tail-siphon withdrawal reflex, supresses long-term but not short-term sensitization, and attenuates sensory-to-motor neuron synapses in Aplysia. $\mathrm{J}$ Neurosci 13:1688-1700.

Gunning PW, Kaye PL, Austin L (1977) In vivo synthesis of rapidlylabelled RNA within the rat nodose ganglia following vagotomy. J Neurochem 28:1245-1248.

Hall ME (1982) Changes in synthesis of specific proteins in axotomized dorsal root ganglia. Exp Neurol 76:83-93.

Helgren ME, Goldberger ME (1993) The recovery of postural reflexes and loconotion following low thoracic hemisection in adult cals involves compensation by undamaged primary afferent pathways. Exp Neurol 123:17-34.

Herrera AA, Grinnell AD (1981) Contralateral denervation causes enhanced transmitter release from frog motor nerve terminals. Nature 291:495-497.

Hoffman PN, Cleveland DW, Griffin JW, Landes PW, Cowan NJ, Price DL (1987) Neurofilament gene expression: a major determinant of axonal caliber. Proc Natl Acad Sci USA 84:3472-3476.

Jahan-Parwar B, Fredman SM (1978) Pedal locomotion in Aplysia californica. I. Sensory and motor fields of pedal nerves. Comp Biochem Physiol 60A:459-465.

Kennedy TE, Kuhl D, Barzilai A, Sweatt JD, Kandel ER (1992) Longterm sensitization training in Aplysia leads to an increase in calreticulin, a major presynaptic calcium-binding protein. Neuron 9:10131024.

Koo EH, Hoffman PN, Price DL (1988) Levels of neurotransmitter and cytoskeletal protein mRNAs during nerve regeneration in sympathetic ganglia. Brain Res 449:361-363.

I asek R.J, Oblinger MM, Drake PF (1983) Molecular biology of neuronal geometry: expression of neurofilament genes influences axonal diameter. Cold Spring Harbor Symp Quant Biol 48:731-744.

Nocl F, Nunez-Regueiro M, Cook R, Byrne JH, Eskin A (1993) Longterm changes in synthesis of intermediate filament protein, actin and other proteins in pleural sensory neurons of Aplysia produced by an in vitro analogue of sensitization training. Mol Brain Res 19:203210.

Oblinger MM, Szumlas RA, Wong J, Liuzzi FJ (1989) Changes in cytoskeletal gene expression affect the composition of regenerating axonal sprouts elaborated by dorsal root ganglion neurons in vivo. $\mathrm{J}$ Neurosci 9:2645-2653.

Opas M, Dziak E, Fliegel L, Michalak M (1991) Regulation of expression and intracellular distribution of calreticulin, a major calcium binding protein of nonmuscle cells. J Cell Physiol 149:160-171.

Pieroni JP, Byrne JH (1992) Differential effects of serotonin, FMRFamide and small cardioactive peptide on multiple, distributed processes modulating sensorimotor synaptic transmission in Aplysia. J Neurosci 12:2633-2647.

Pinsker HM, Hening WA, Carew TJ, Kandel ER (1973) Long-term sensitization of a defensive withdrawal reflex in Aplysia. Science 182: $1039-1042$.

Raymond JL, Byrne JH (1994) Distributed input to the tail-siphon withdrawal circuit in Aplysia from neurons in the $\mathrm{J}$ cluster of the cerebral ganglion. J Neurosci 14:2444-2454.

Reimer D, Dodemont H, Weber K (1991) Cloning of the non-neuronal intermediate filament protein of the gastropod Aplysia californica; identification of an amino acid residue essential for the IFA epitope. Eur J Cell Biol 56:351-357.

Rotshenker S (1982) Transneuronal and peripheral mechanisms for the induction of motor neuron sprouting. J Neurosci 2:1359-1368.

Rotshenker S (1988) Multiple modes and sites for the induction of axonal growth. Trends Neurosci 11:363-366.

Rutherford SD, Widdop RE, Louis WJ, Gundlach AL (1992) Preprogalanin mRNA is increased in vagal motor neurons following axotomy. Mol Brain Res 14:261-266.

Savage MI, Buriani A, Goldberg D. (1990) Target regulation of axotomy-sensitive proteins. J Neurochem 54:270-2076.

Schaefer M, Picciotto MR, Kreiner T, Kaldany RR, Taussig R, Scheller RH (1985) Aplysia neurons express a gene encoding multiple FMRFamide neuropeptides. Cell 41:457-467.

Schmied R, Huang CC, Zhang XP, Ambron DA, Ambron RT (1993) Endogenous axoplasmic proteins and proteins containing nuclear localization signal sequences used the retrograde axonal transport/nuclear import pathway in Aplysia neurons. J Neurosci 1993 13:40644061.

Scheff SW, Cotman CW (1977) Recovery of spontaneous alternation 
following lesions of the entorhinal cortex in adult rats: possible correlation to axon sprouting. Bev Biol 21:286-293.

Scott ML, Kirk MD (1992) Recovery of consummatory feeding behavior after bilateral lesions of the cerebral-buccal connectives in Aplysia californica. Brain Res 585:272-274.

Skene JHP, Willard M (1981) Changes in axonally transported proteins during axon regeneration in toad retinal ganglion cells. J Cell Biol 89:86-95.

Skene JHP (1989) Axonal growth-associated proteins. Ann Rev Neurosci 12:127-156.

Smith MJ, Koch GLE (1989) Multiple zones in the sequence of calreticulin (CRP55, calregulin, HACBP), a major calcium binding ER/ SR protein. EMBO J 8:3581-3586.

Smith SJ (1988) Neuronal cytomechanics: the actin-based motility of growth cones. Science 242:708-715.

Steward O, Cotman CW, Lynch GS (1973) Re-establishment of electrophysiological functional entorhinal cortical input to the dentate gyrus deafferented by ipsilateral enorhinal lesions: innervation by the contralateral entorhinal cortex. Exp Brain Res 18:396-414.

Steward O, Cotman CW, Lynch GS (1976) A quantitative autoradiographic and electrophysiological study of the reinnervation of the dentate gyrus by the contralateral entorhinal cortex following ipsilateral enturhinal lesions. Brain Res 114:181-200.
Stodieck LS, Beel AJ, Luttges MW (1986) Structural properties of spinal nerve roots: protein composition. Exp Neurol 91:41-51.

Tetzlaff W, Bisby MA, Kreutzberg GW (1988) Changes in cytoskeletal proteins in the rat facial nucleus following axotomy. J Neurosci 8:3181-3189.

Walters ET, Ambron RT (1995) Long-term alterations induced by injury and by 5-HT in Aplysia sensory neurons: convergent pathways and common signals? Trends Neurosci 18:137-142.

Walters ET, Byrne JH, Carew TJ, Kandel ER (1983) Mechanoafferent neurons innervating tail of Aplysia. I. Response properties and synaptic connections. J Neurophysiol 50:1522-1542.

Walters ET, Alizadeh H, Castro GA (1991) Similar neuronal alterations induced by axonal injury and learning in Aplysia. Science 253:797799.

Wright WG, Marcus EA, Carew TJ (1991) A cellular analysis of inhibition in the siphon withdrawal reflex of Aplysia. J Neurosci 11:22509.

Xu Y, Cleary LJ, Byrne JH (1994) Identification and characterization of pleural neurons that inhibit tail sensory neurons and motor neurons in Aplysia: correlation with FMRFamide immunoreactivity. J Neurosci 14:3565-3577.

Zhang X, Verge MKV, Weisenfeld-Hallin Z, Piehl F, Hökfelt T (1993) Expression of neuropeptides and neuropeptide mRNAs in spinal cord after axotomy in the rat, with special reference to motorneurons and galanin. Exp Brain Res 93:450-461. 